\title{
INCREASE STUDENT ACTIVITY IN MATHEMATICS USING COOPERATIVE LEARNING MODEL TYPE OF THINK PAIR SQUARE (TPS)
}

\author{
Istin Fauziah ${ }^{\text {a }}$, Abdul Taram ${ }^{\mathrm{b}}$ \\ Program Studi Pendidikan Matematika Universitas Ahmad Dahlan \\ Jalan Ring Road Selatan, Tamanan, Banguntapan, Bantul Yogyakarta \\ aistinfauziah1@gmail.com,
}

\begin{abstract}
The research was conducted because of low student activity in learning mathematics. The purpose of this research is to improve the activity of students in learning mathematics using the cooperative learning model of think pair square (TPS) in class VII of even semester at SMP Muhammadiyah 2 Prambanan. This research was conducted at SMP Muhammadiyah 2 Prambanan. The type of research is classroom action research. Subjects of this research were students of class VII of even semester at SMP Muhammadiyah 2 Prambanan academic year 2015/2016, amounting to 35 students. The object of the research is a cooperative learning model type TPS. Data analysis used qualitative descriptive analysis. The research instruments are student activity observation sheets, teacher activity observation sheets, and interview guides. Success in learning characterized by an increased average percentage of student activity achieved at least a good criteria $(\geq 61 \%)$. The result of this research indicates that the use of mathematical models of cooperative learning type of TPS can enhance student activity. From the observation sheet, there was an increase in student activity with the student in learning mathematics using TPS. In the first cycle, the average student activity reached $57,857 \%$ with enough criteria, and the second cycle increased to $64,584 \%$ with good criteria. From interview showed a positive response from students to use cooperative learning model type TPS.
\end{abstract}

Keywords: CAR, Activity Learning, Think Pair Square (TPS)

\section{INTRODUCTION}

Education is the most important role for every nation especially for a developing nation like the Indonesian people. Education is also one effort in answering problems and various challenges that are always present during human life. Mathematics is a basic science that must be mastered in developing science and technology. Mathematics is also a means for thinking and reasoning, so mathematics plays an important role in educating the life of the nation and advancing science and technology. Mathematics as one of the subjects in school is not only used to train thinking intelligence but also can shape the personality of students in developing certain skills. In the process of learning mathematics, students tend to be passive so that students do not understand the subject matter and when students are given questions they will find it difficult to solve it. Therefore, the mathematical learning model applied in schools needs to be developed to increase student activity in the classroom. Active learning is an atmosphere of learning that makes students active and fully participates in learning. An interesting learning model can also influence student learning activities.

According to Michelin et al (2012: 36), think Pair Square type Cooperative Learning models can allow students to work alone and work with others. The cooperative learning model thinks pair square also provides opportunities for students to discuss their ideas and provide an understanding for them to see other ways of solving problems. The characteristics of TPS type cooperative learning are (Lie, A 2008: 58) as follows: (1) the teacher divides students into groups of four and assigns assignments to all groups, (2) each student thinks and does the task himself (3) students pair up with one partner in one group and discuss with their partner, (4) both partners meet again in a group of four.

The advantages of this cooperative type TPS learning model (Lie, A 2008: 57) include: (1) optimizing student participation in learning activities, (2) students can increase motivation and get a design for thinking, (3) students will have more discussion, (4) each student has the opportunity to discuss with students who are smarter or weaker, (5) in groups of four, teachers more easily divide students into pairs, (6) teacher dominance in learning decreases. 
According to (Lie, A 2008: 58), the syntax or stages of the implementation of learning with TPS are as follows (1) the preliminary stage of students is divided into four groups, (2) think (think individually), (3) pair (pair), (4) Square (sharing answers with other partners in one group), (5) Class Discussion, (6) Group Award Stage. The success of the teaching and learning activities process can be measured by the success of students who take part in these learning activities. Success in learning can be seen from the level of understanding, mastery of the material and student learning outcomes. One that influences the good or bad of the learning process is student learning activities, where if learning activities are good then the results obtained will also be good. According to Silbeman, Melvin (2013: 9), for learning to be active, students must do many tasks. They must use the brain, study ideas, solve problems, and apply what they learn. Active learning must be nimble, excited and passionate. "

According to the Directorate of Guidance (2010: 57-58) about the technical guidelines for the preparation of affective assessment tools, student activities in mathematics learning can be seen from (1) student enthusiasm in participating in learning, (2) student and teacher interaction, (3) interaction between students (4) group collaboration, (5) student activity in groups and (6) student participation in summarizing the results of the discussion. Therefore the role of the teacher becomes very important for the learning process. Not only encouragement and enthusiasm, but also a teaching process that is not monotonous, making students feel bored. Cooperative learning models can be applied by a teacher in the process of learning mathematics. The cooperative learning model has a variety of types, one model that is thought to be able to improve student learning activities is Think Pair Square (TPS).

Learning using this TPS model provides more opportunities for students to interact with groups, discuss, answer questions, look for answers, explain, and listen to the material explained. The stages of this TPS cooperative learning process are the first, Think. At the Think stage, students think for themselves the steps to solve existing problems. Then the Pair stage, at this stage students discuss with their partners. The last stage is Square, at this stage students discuss with the group. The formulation of the problem in this study is "Does the use of the TPS type cooperative learning model improve the learning activities of Grade VII students of SMP Muhammadiyah 2 Prambanan 2015/2016 Academic Year?". The purpose of this study is to find out whether using the TPS type cooperative learning model can improve the learning activities of Grade VII students of SMP Muhammadiyah 2 Prambanan in the 2015/2016 Academic Year.

\section{METHODS}

This research is Classroom Action Research (CSR). The subject of this study was the seventhgrade students of SMP Muhammadiyah 2 Prambanan in the even semester of the 2015/2016 academic year with a total of 35 people, and the object in this study was the mathematics learning process using the TPS cooperative learning model. The research procedure used in this CSR consists of three cycles. Learning at the Cycle I, Cycle II and Cycle III stages using the TPS cooperative learning model then the researcher acts as the teacher. According to Suharsimi Arikunto, et al ((2012: 16-20), the activities carried out in each cycle are as follows (1) planning, (2) implementation of actions, (3) observation and (4) reflection.

At this planning stage, the researcher prepares and prepares things as follows (1) plan for implementing learning (RPP) (2) observation sheet for student activity (3) teacher observation sheet, (4) student interview sheet (5) student worksheet. At the stage of implementation of the action, the activities carried out by the researcher were to implement the RPP that had been made which is to do learning with the TPS learning model. The material discussed is about triangles and rectangles with the details as follows (1) in the first cycle of the first meeting to discuss the material of triangular elements (2) in the first cycle of the second meeting discussing material calculating circumference and area width (3) in the second cycle of the meeting The first discusses square and rectangular material, and (4) in the second cycle the second meeting discusses the material in the length and trapezoid.

At this observation, stage researchers are assisted by grade VII mathematics teachers who act as observers who observe all student learning activities while learning activities take place. At the stage of 
reflection, researchers and observers conduct a discussion to evaluate the teaching and learning process that has taken place and develop an action plan in the next cycle. Data collection techniques used in this study are as follows (1) observations were made to determine student learning activities during the learning process takes place (2) interviews were conducted on several students at the end of each cycle meeting, (3) this documentation in the form of photographs, group names, and the names of students, and (4) triangulation is defined as a technique of collecting data that has the character of combining various existing data collection techniques and data sources (Sugiyono, 2010: 330). Triangulation is used to find out the data obtained to make it clearer, consistent, complete and certain. Analysis of student activity data in mathematics learning using the formula:

$$
\mathrm{NP}=\frac{R}{S M} \times 100
$$

Information:

$N P \quad=$ Percent sought

$R \quad=$ raw score obtained by students

$S M \quad=$ Ideal maximum score from the test in question

$100=$ Fixed number

( Ngalim Purwanto, 2013:102)

The criteria for the P-value can be seen in the following table:

Table 1. Criteria for Value $P$

\begin{tabular}{|l|c|}
\hline Percentage of responses (\%) & Criteria \\
\hline $81 \% \leq \mathrm{P} \leq 100 \%$ & Very well \\
\hline $61 \% \leq \mathrm{P}<81 \%$ & Well \\
\hline $41 \% \leq \mathrm{P}<61 \%$ & Enough \\
\hline $21 \% \leq \mathrm{P}<41 \%$ & Less \\
\hline$<21 \%$ & Less once \\
\hline
\end{tabular}

(Suharsimi Arikunto dan Cepi Safruddin A.J, 2014:35)

The indicator of the success of this study is that students' learning activities in mathematics learning increase, that is if student activities reach at least a good criterion of $61 \%$.

\section{RESULTS AND DISCUSSION}

From the results of observations on student activities, it can be seen that there was an increase in student activity during learning using the TPS type cooperative learning model on the subject of triangles and rectangles. Increased student learning activities can be seen in the following table:

Table 2. Analysis of Results of Observation of Activity of Cycle I and Cycle II Students

\begin{tabular}{|c|l|c|c|c|}
\hline \multirow{2}{*}{ No } & \multicolumn{1}{|c|}{ Indicator } & \multicolumn{2}{|c|}{ Percentage } & \multirow{2}{*}{ Information } \\
\cline { 3 - 4 } & & Cycle I & Cycle II & \\
\hline 1 & Enthusiasm of students in learning & $58,929 \%$ & $68,214 \%$ & Increase \\
\hline 2 & Student and teacher interaction & $58,562 \%$ & $65,000 \%$ & Increase \\
\hline 3 & Interaction between students & $57,857 \%$ & $64,643 \%$ & Increase \\
\hline 4 & Group collaboration & $56,429 \%$ & $62,857 \%$ & Increase \\
\hline 5 & Student activities in groups & $58,214 \%$ & $65,715 \%$ & Increase \\
\hline 6 & $\begin{array}{l}\text { Student participation in concluding the } \\
\text { results of the discussion }\end{array}$ & $56,789 \%$ & $61,072 \%$ & Increase \\
\hline \multicolumn{2}{|c|}{ Average } & $57,857 \%$ & $64,584 \%$ & Increase \\
\hline \multicolumn{2}{|c|}{ Criteria } & Enough & Good & Increase \\
\hline
\end{tabular}


For more details, it will be presented in the following graph:

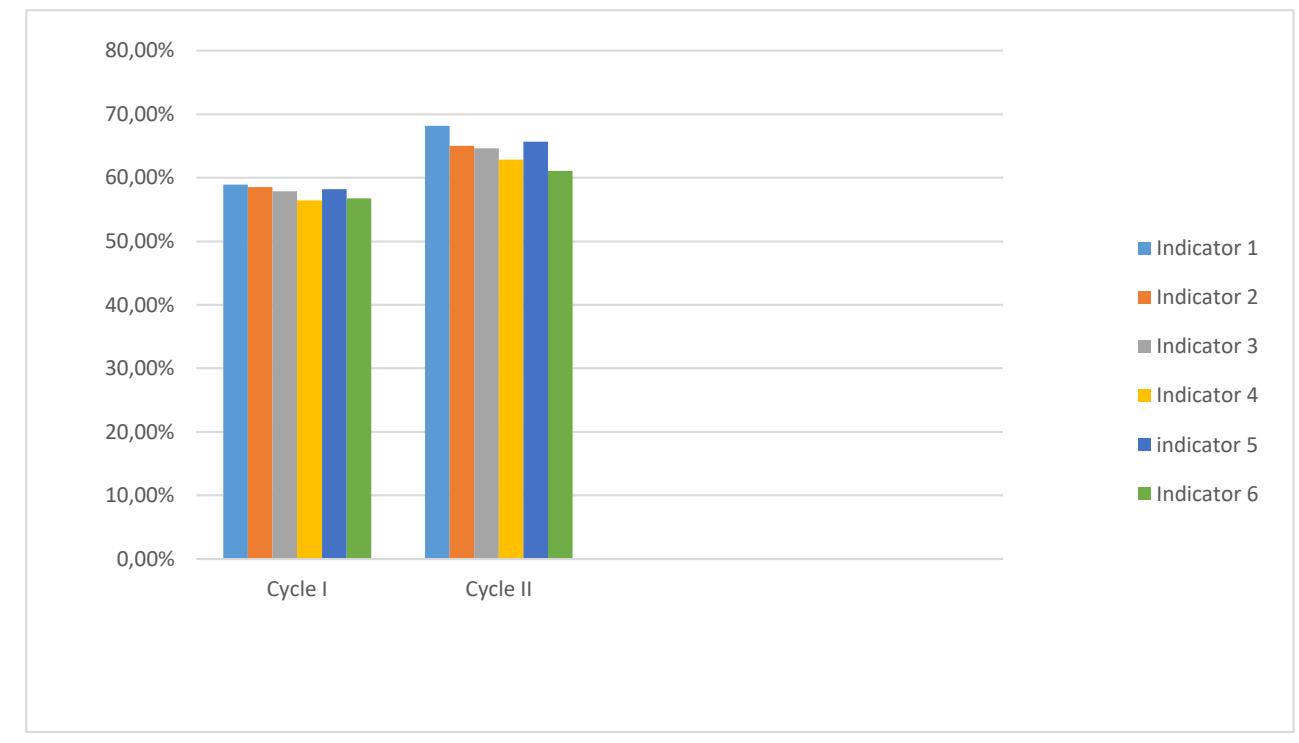

Overall, it can be concluded that mathematics learning using the cooperative learning model think pair square type can be used as a way to improve the seventh-grade mathematics learning activities of SMP Muhammadiyah 2 Prambanan Semester II 2015/2016 academic year. Thus the hypothesis of action that is through cooperative learning type Think Pair Square can increase accepted mathematics learning activities.

\section{CONCLUSION}

Based on the description above, it can be concluded that there is an increase in student activity while applying the TPS type cooperative learning model. Student learning activities that experience improvement are students' enthusiasm in participating in learning, the interaction between students, activities asking the teacher about the material delivered by the teacher, student activities discussing in groups, student activities able to work together in solving a problem with his group friends and student participation in concluding discussion result.

\section{REFERENCES}

Direktorat Jendral Manajemen Pendidikan Dasar dan Menengah. 2010. Pelaksanaan Penilaian dalam Implementasi KTSP Kementrian Pendidikan Nasional. Jakarta: Direktorat Pembinaan.

Lie, Anita. 2008. Cooperative Learning Mempraktikkan Cooperative Learning di Ruang-Ruang Kelas. Jakarta: Grasindo.

Michelin dkk. 2012. Model Cooperativen Learning tipe Think Pair Square dalam Pembelajaran Matematikadi Kelas VII SMPN 1 Pulau Punjung. Jurnal Pendidikan Matematika (Vol. 1 No. 1). Halaman 35-38. Diakses tanggal 10 desember 2015

Ngalim Purwanto. 2013. Prinsip-prinsip dan teknik evaluasi pengajaran. Bandung: PT Remaja Rosdakarya.

Silberman, Melvin. 2012. Aktive Learning. Bandung: Nuansa cendekia.

Suharsimi Arikunto dkk. 2012. Penelitian Tindakan Kelas. Jakarta. Bumi Aksara.

Suharsimi Arikunto dan Cepi Safrudin Abdul Jabar. 2014. Evaluasi Program Pendidikan Pedoman Teoritis Praktik Bagi Praktisi pendidikan. Jakarta:Bumi Aksara.

Sugiyono. 2010. Metode Penelitian Pendidikan (Pendekatan Kuantitatif, Kualitatif, dan R\&D). Bandung: Alfabeta. 